\title{
Synthetic Amphipathic Helical Peptides That Mimic Apolipoprotein A-I in Clearing Cellular Cholesterol
}

Armando J. Mendez, * G. M. Anantharamaiah, ${ }^{\ddagger}$ Jere P. Segrest, ${ }^{\star}$ and John F. Oram ${ }^{\star}$

*Department of Medicine RG-26, University of Washington, Seattle, Washington 98195; and ${ }^{\ddagger}$ Department of Medicine and Biochemistry, and the Atherosclerotic Research Unit,

University of Alabama at Birmingham Medical Center, Birmingham, Alabama 35294

\begin{abstract}
Clearance of excess cholesterol from cells by HDL is facilitated by the interaction of HDL apolipoproteins with cellsurface binding sites or receptors, a process that may be important in preventing atherosclerosis. In this study, synthetic peptides containing 18-mer amphipathic helices of the class found in HDL apolipoproteins (class A) were tested for their abilities to remove cholesterol and phospholipid from cultured sterol-laden fibroblasts and macrophages and to interact with cell-surface HDL binding sites. Lipid-free peptides containing two identical tandem repeats of class $A$ amphipathic helices promoted cholesterol and phospholipid efflux from cells and depleted cellular cholesterol accessible for esterification by acyl CoA/cholesterol acyltransferase, similar to what was observed for purified apolipoprotein AI. Peptide-mediated removal of plasma membrane cholesterol and depletion of acyl CoA/cholesterol acyltransferaseaccessible cholesterol appeared to occur by separate mechanisms, as the latter process was less dependent on extracellular phospholipid. The dimeric amphipathic helical peptides also competed for high-affinity HDL binding sites on cholesterol-loaded fibroblasts and displayed saturable high-affinity binding to the cell surface. In contrast, peptides with a single helix had little or no ability to remove cellular cholesterol and phospholipid, or to interact with HDL binding sites, suggesting that cooperativity between two or more helical repeats is required for these activities. Thus, synthetic peptides comprising dimers of a structural motif common to exchangeable apolipoproteins can mimic apolipoprotein A-I in both binding to putative cell-surface receptors and clearing cholesterol from cells. (J. Clin. Invest. 1994. 94:1698-1705.) Key words: synthetic peptides - amphipathic helices $\bullet$ high-density lipoprotein - cellular cholesterol efflux $•$ HDL receptors
\end{abstract}

\section{Introduction}

The role of HDL in promoting the removal of excess cholesterol from cultured cells has been well established; however, mecha-

Address correspondence to John F. Oram, Department of Medicine RG26, University of Washington, Seattle, WA 98195. 1994.

Received for publication 27 April 1993 and in revised form 2 June

J. Clin. Invest.

(C) The American Society for Clinical Investigation, Inc.

0021-9738/94/10/1698/08 $\$ 2.00$

Volume 94, October 1994, 1698-1705 nisms by which this occurs remain poorly understood. HDL appears to remove cholesterol from cells by both passive and active processes. Cholesterol that is synthesized by cells or ingested by receptor-mediated endocytosis of lipoproteins can be transported rapidly to the plasma membrane where it passively desorbs into the extracellular fluid and reabsorbs to phospholipid-containing particles $(1,2)$. When cells are overloaded with sterol, however, cholesterol accumulates within an intracellular pool that is accessible to the enzyme acyl CoA/cholesterol acyltransferase (ACAT), ${ }^{1}$ thus allowing cells to store excess cholesterol as ester-rich lipid droplets. Under this condition, excretion of excess ACAT-accessible cholesterol can be facilitated by an active process $(3,4)$ that is stimulated by the interaction of HDL apolipoproteins with cell-surface binding sites or receptors (5).

A common secondary structural motif described for the plasma lipoprotein-associated apolipoproteins is the amphipathic helix (reviewed in 6 and 7). Based on the properties of amphipathic helices found in the exchangeable apolipoproteins, a synthetic peptide, designated $18 \mathrm{~A}$, was designed and synthesized (8-10). This class A amphipathic helical peptide has been shown to form stable complexes with phospholipids similar to those formed by apolipoprotein A-I, the major protein constituent of HDL (8-10). A dimer of 18A linked with a proline residue $(37 \mathrm{pA})$ has greater lipid affinity than $18 \mathrm{~A}$, presumably due to cooperativity provided by two covalently linked lipidbinding peptides. In contrast, an analogue of $18 \mathrm{~A}(18 \mathrm{R})$, with the position of charged residues reversed along the polar face of the helix, can only marginally interact with lipid (8-10). Synthetic amphipathic helices can mimic several of the biological effects of apo A-I, and the potencies of these effects are related to the lipid binding affinities of the synthetic peptides (11-15). The present study examines whether these synthetic amphipathic peptides could also mimic the ability of lipid-free apo A-I and HDL to promote efflux of excess cholesterol from cultured cells and to interact with HDL binding sites on the cell surface.

\section{Methods}

Lipoprotein and apolipoprotein isolation. LDL and $\mathrm{HDL}_{3}$ (hereafter referred to as HDL) were prepared by sequential ultracentrifugation in the density intervals 1.019 to 1.063 and 1.125 to $1.21 \mathrm{~g} / \mathrm{ml}$, respectively. LDL was acetylated by the method of Goldstein et al. (16) and labeled

1. Abbreviation used in this paper: ACAT, acyl CoA/cholesterol acyltransferase. 
with $\left[{ }^{3} \mathrm{H}\right]$ cholesteryl linoleate as described (17). HDL was iodinated by the iodine monochloride method described by Bilheimer (18). apo A-I was purified from HDL as previously described (4). Purified apo A-I exhibited a single band when examined by sodium dodecyl sulfate polyacrylamide gel electrophoresis with Coomassie blue staining.

Phospholipid vesicles. Vesicles were prepared by the cholate dialysis method (19). For cell culture experiments, the vesicles were added to the medium immediately prior to adding the medium to cells.

Peptides. Peptides were synthesized and purified as described previously (9). The primary sequences of the peptides used in this study are shown in Table I.

Cell culture. Human skin fibroblasts were cultured and maintained as previously described $(4,5,18)$. Usually 70,000 cells $/ 2 \mathrm{ml}$ medium in $35 \mathrm{~mm}$ dishes or 15,000 cells $/ 1 \mathrm{ml}$ medium in $16 \mathrm{~mm}$ wells were seeded and grown to confluence before use in experiments. Cells were loaded with nonlipoprotein cholesterol by incubation for $48 \mathrm{~h}$ with DME containing $2 \mathrm{mg} / \mathrm{ml}$ fatty acid-free BSA (Sigma Chemical Co., St. Louis, MO) and $30 \mu \mathrm{g} / \mathrm{ml}$ cholesterol. Cells were then incubated overnight $(16-18 \mathrm{~h})$ in DME containing $1 \mathrm{mg} / \mathrm{ml} \mathrm{BSA}$ and $0.2 \mu \mathrm{Ci} / \mathrm{ml}$ $\left[{ }^{3} \mathrm{H}\right]$ cholesterol $(40-60 \mathrm{Ci} / \mathrm{mmol}$, Amersham Corp., Arlington Heights, IL) to label plasma membrane cholesterol. For experiments containing $\left[{ }^{3} \mathrm{H}\right]$ choline-labeled phospholipids (see below), cells were labeled with $0.1 \mu \mathrm{Ci} / \mathrm{ml}\left[{ }^{14} \mathrm{C}\right.$ ] cholesterol (50-60 Ci/mmol, Amersham Corp.). Choline-containing phospholipids were labeled by including $1 \mu \mathrm{Ci} / \mathrm{ml}$ $\left[{ }^{3} \mathrm{H}\right]$ choline chloride $(75-85 \mathrm{Ci} / \mathrm{mmol}$, Amersham Corp.) during the overnight incubation of fibroblasts. After incubation with radiolabel, cell layers were rinsed five times with PBS containing 0.1\% BSA (PBS/ BSA) before the addition of experimental media.

Resident mouse peritoneal macrophage cultures were established from unstimulated Swiss Webster mice by the method of Edelson and Cohn (20). Peritoneal cells were harvested from 20-25 mice in PBS, pooled at $4^{\circ} \mathrm{C}$, collected by centrifugation $\left(400 \mathrm{~g}, 10 \mathrm{~min}, 4^{\circ} \mathrm{C}\right)$, and washed once in DME. Cells were plated in DME containing 20\% (vol/ vol) FBS at $1 \times 10^{6}$ cells $/ 0.5 \mathrm{ml} / 16 \mathrm{~mm}$ well. After incubation for 2 $\mathrm{h}$ at $37^{\circ} \mathrm{C}$, nonadherent cells were removed by washing three times with DME. Adherent cells were maintained in culture with DME containing $20 \%$ total bovine serum for $5 \mathrm{~d}$ before use in experiments. Macrophages were cholesterol loaded by incubation with $50 \mu \mathrm{g} / \mathrm{ml}$ of $\left[{ }^{3} \mathrm{H}\right]$ cholesteryl linoleate-labeled acetylated-LDL for $24 \mathrm{~h}$. Cells were then washed two times with serum-free DME and incubated overnight with serum-free DME to allow equilibration of cholesterol pools.

Cholesterol and phospholipid efflux from cells. After the appropriate labeling protocol, cells were incubated at $37^{\circ} \mathrm{C}$ with DME containing 1 $\mathrm{mg} / \mathrm{ml} \mathrm{BSA}$ and the indicated additions. At the indicated times, the efflux media were collected and cell layers were rinsed three times with PBS. Media and cells were stored frozen at $-20^{\circ} \mathrm{C}$ until extraction for lipid and protein content. Efflux media were extracted by the method of Folch et al. (21) and, in some experiments (labeled with cholesterol), counted directly after a brief centrifugation to remove cell debris. Cholesterol-labeled cell layers were extracted with hexane/isopropanol ( $3: 2$, $\mathrm{vol} / \mathrm{vol})$ as described $(5,17)$. Cells containing labeled phospholipids were extracted with $1 \mathrm{ml}$ of isopropanol for $1 \mathrm{~h}$, and then with hexane/ isopropanol as above.

Sterol species were separated by thin layer chromatography on silica gel $\mathrm{G}$ plates developed in hexane/diethyl ether/methanol/acetic acid (120:30:10:1.5, vol:vol:vol:vol). Choline-containing phospholipids were separated by thin layer chromatography on silica gel $\mathrm{H}$ plates developed in chloroform/methanol/water (65:35:4, vol:vol:vol). Lipid spots were identified by staining with $\mathbf{I}_{2}$ vapor and comigration with standards. After allowing $I_{2}$ stain to dissipate, appropriate spots were taken for determination of sterol mass and/or scintillation counting. Labeled cholesterol efflux and labeled phospholipid efflux were calculated as the percent of label appearing in the media, relative to the total (media + cell) radioactivity for each lipid.

Cell cholesterol esterification. To assess the relative activity of ACAT following incubation with test medium, cells were washed once with PBS and incubated for $1 \mathrm{~h}$ at $37^{\circ} \mathrm{C}$ with DME containing $9 \mu \mathrm{M}$ ${ }^{14} \mathrm{C}$-oleate $(50-60 \mathrm{mCi} / \mathrm{mmol}$, Amersham Corp.) bound to $3 \mu \mathrm{M}$ BSA
(5). Cells were chilled on ice and washed twice with PBS/BSA and twice with PBS. Cells were stored frozen at $-20^{\circ} \mathrm{C}$ until extraction for lipid and protein as described above. Cell lipids were separated by thin layer chromatography as described above to determine cholesteryl ester radioactivity. Incorporation of radiolabel into cholesterol esters represents cholesterol esterification by ACAT, and results were quantitated as picomoles of $\left[{ }^{14} \mathrm{C}\right]$ oleate incorporated into cholesteryl esters per milligram of cell protein.

Cell-surface binding of HDL and peptides. The specificity of highaffinity HDL binding sites on fibroblasts was tested using a sequential competitive binding assay (22). Cholesterol-loaded fibroblasts were washed twice with PBS/BSA and chilled on ice during a third wash. Cells were then incubated at $0^{\circ} \mathrm{C}$ (on ice) with Hepes-buffered DME containing $1 \mathrm{mg} / \mathrm{ml} \mathrm{BSA}$ and the indicated concentration of competitor. After $3 \mathrm{~h}$, the cells were rapidly washed three times with ice-cold PBS/ BSA and incubated for $1 \mathrm{~h}$ at $0^{\circ} \mathrm{C}$ with Hepes-buffered DME containing $1 \mathrm{mg} / \mathrm{ml} \mathrm{BSA}$ and $5 \mu \mathrm{g} / \mathrm{ml}$ of ${ }^{125} \mathrm{I}-\mathrm{HDL}$. Specific activity of ${ }^{125} \mathrm{I}-\mathrm{HDL}$ ranged from 200 to $300 \mathrm{cpm} / \mathrm{ng}$ HDL protein with less than $2 \%$ of label associated with lipids. Cells were washed five times with ice-cold PBS/ BSA and twice with PBS. Cell layers were dissolved in $0.1 \mathrm{M} \mathrm{NaOH}$, and aliquots were taken to quantitate radioactivity and protein.

To measure direct binding of peptides $18 \mathrm{~A}$ and $37 \mathrm{pA}$ to the cell surface, tyrosyl residues were labeled with ${ }^{125} \mathrm{I}$ by the iodine monochloride method $(18,23)$, and radiolabeled peptides were extensively dialyzed. The specific activities of the peptides ranged from 800 to 2,200 $\mathrm{cpm} / \mathrm{pmol}$. Fibroblasts were incubated with $10 \mathrm{nM}$ to $2 \mu \mathrm{M}$ radiolabeled peptide for $3 \mathrm{~h}$ at $0^{\circ} \mathrm{C}$ as described above for binding of ${ }^{125} \mathrm{I}-\mathrm{HDL}$. Iodination of the peptides had no effect on biological activity based on results showing that iodination of $37 \mathrm{pA}$ did not change its ability to inhibit cellular cholesterol esterification and that unlabeled $37 \mathrm{pA}$ blocked cell-surface binding of iodinated $37 \mathrm{pA}$ (data not shown).

Other methods. Protein concentrations were estimated by the method of Lowry et al. (24) using BSA as the standard. Statistical differences were calculated by Student's $t$ test. Kinetic analyses of peptide binding and lipid efflux were performed using the SAAM30 computer program.

\section{Results}

The effects of HDL, apo A-I, and synthetic amphipathic helical peptides on cholesterol clearance from cultured human skin fibroblasts were determined by two independent assays. First, as an index of cholesterol efflux from the plasma membrane, the appearance of radiolabeled cholesterol in the medium was measured after cholesterol-loaded cells were labeled overnight with trace quantities of $\left[{ }^{3} \mathrm{H}\right]$ cholesterol. Second, depletion of cellular pools accessible for esterification by ACAT was estimated by the decrease in incorporation of $\left[{ }^{14} \mathrm{C}\right]$ oleate into cholesteryl esters. Results show that HDL and lipid-free apo AI can promote $\left[{ }^{3} \mathrm{H}\right]$ cholesterol efflux and decrease cholesterol esterification (Fig. 1, $A$ and $B$ ). Both apo A-I and HDL had maximal effects on cholesterol esterification at $\sim 400 \mathrm{nM}$, although HDL had a greater capacity to promote $\left[{ }^{3} \mathrm{H}\right]$ cholesterol efflux, presumably because of exchange between HDL cholesterol and plasma membrane tracer $(1,2)$.

The synthetic peptides $18 \mathrm{~A}$ and the charge-reversed analogue 18R ( see Table I) had no significant effect on cholesterol efflux or esterification, even at molar concentrations 20 -fold higher than that for HDL (Fig. $1 C$ ). To increase the $\alpha$-helical potential and the lipid-binding properties of $18 \mathrm{~A}$, the $\mathrm{NH}_{2}$ - and $\mathrm{COOH}$-terminal groups were protected by acetyl and $\mathrm{NH}_{2}$ groups, respectively (15). This modification of peptide 18A did not affect cholesterol efflux from cells (Fig. $1 E$ ). The increased cholesterol esterification caused by Ac-18A- $\mathrm{NH}_{2}$ appeared to reflect enhanced uptake of $\left[{ }^{14} \mathrm{C}\right]$ oleate as indicated by a parallel increase in incorporation of label into triglycerides (data not 


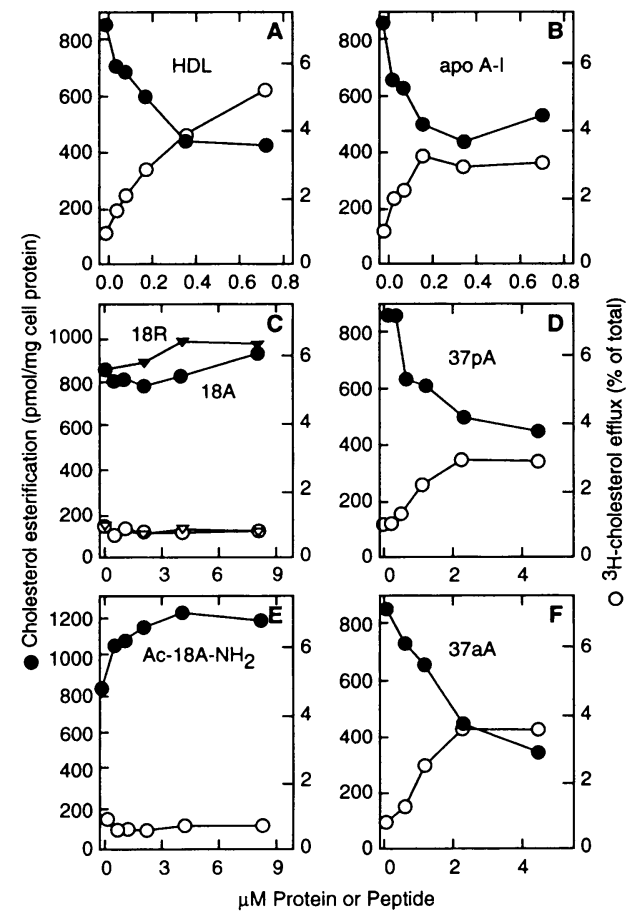

Figure 1. Effect of HDL, apo A-I, and synthetic amphipathic helical peptides on cellular cholesterol efflux and esterification. Cholesterolloaded human skin fibroblasts, labeled with $\left[{ }^{3} \mathrm{H}\right]$ cholesterol, were incubated with serum-free DME containing $1 \mathrm{mg} / \mathrm{ml} \mathrm{BSA}$ and the indicated concentrations of HDL or peptide. After $6 \mathrm{~h}$, the medium was removed and cells were further incubated for $1 \mathrm{~h}$ with medium containing ${ }^{14} \mathrm{C}$ oleate to measure cholesterol esterification by ACAT. Cell and medium lipids were extracted and separated by thin-layer chromatography, and cholesterol and cholesteryl ester radioactivity was quantitated. Cholesterol efflux (open symbols) was calculated as the percent of total (cell and medium) $\left[{ }^{3} \mathrm{H}\right]$ cholesterol appearing in the medium. Total $\left[{ }^{3} \mathrm{H}\right]-$ cholesterol counts were $18,605 \pm 1,211 \mathrm{cpm} /$ dish. Cholesterol esterification ( closed symbols) was calculated as picomoles of ${ }^{14} \mathrm{C}$-oleate incorporated into cholesteryl esters normalized for cell protein. The results are the means of duplicate dishes representative of two to five experiments. The coefficients of variation for cholesterol efflux and cholesterol esterification assays were $5.9 \%$ and $6.9 \%$, respectively.

shown). None of the other peptides tested had any effect on incorporation of oleate into triglycerides compared to controls. Thus, even though Ac-18A- $\mathrm{NH}_{2}$ appeared to perturb the lipid environment of the plasma membrane, it was no more active than $18 \mathrm{~A}$ or $18 \mathrm{R}$ in promoting cholesterol efflux.

In contrast to the monomers, dimers of $18 \mathrm{~A}$ linked with proline $(37 \mathrm{pA})$ or alanine $(37 \mathrm{aA})$ were able to inhibit cholesterol esterification and promote $\left[{ }^{3} \mathrm{H}\right]$ cholesterol efflux (Fig. 1, $D$ and $F$ ). The maximum extent of depletion of ACAT substrate for these peptides was comparable to that for HDL and apo AI. Time course studies at saturating concentrations of HDL, apo $\mathrm{A}-\mathrm{I}$, and $37 \mathrm{pA}$ demonstrated equivalent rates for the decrease in cholesterol esterification over $16 \mathrm{~h}$ of incubation, while $18 \mathrm{~A}$ remained without effect (data not shown).

The synthetic peptides were compared to HDL and apo AI for their ability to promote clearance of cholesterol from sterolladen mouse peritoneal macrophages, a cultured cell model with features common to foam cells of atherosclerotic lesions (16). Cells were overloaded with cholesterol by incubation with ace-
Table I. Amino Acid Sequence of Synthetic Peptides

\begin{tabular}{|c|c|}
\hline Peptide & Sequence \\
\hline & $-\quad+$ \\
\hline \multirow[t]{2}{*}{$18 \mathrm{~A}$} & $\begin{array}{l}\text { Asp-Trp-Leu-Lys- Ala-Phe-Tyr-Asp-Lys- Val-Ala-Glu- } \\
\quad+\quad+- \\
\text { Lys-Leu-Lys-Glu-Ala-Phe }\end{array}$ \\
\hline & +- \\
\hline $18 \mathrm{R}$ & $\begin{array}{l}\text { Lys-Trp-Leu-Asp-Ala-Phe-Tyr-Lys-Asp-Val-Ala-Lys- } \\
-\quad-\quad+ \\
\text { Glu-Leu-Glu-Lys-Ala-Phe }\end{array}$ \\
\hline $37 \mathrm{pA}$ & 18A-Pro-18A \\
\hline $37 \mathrm{aA}$ & $18 \mathrm{~A}-\mathrm{Ala}-18 \mathrm{~A}$ \\
\hline Ac- $18 \mathrm{~A}-\mathrm{NH}_{2}$ & Acetyl-18A- $\mathrm{NH}_{2}$ \\
\hline
\end{tabular}

tylated-LDL containing $\left[{ }^{3} \mathrm{H}\right]$ cholesteryl linoleate to radiolabel cellular pools of free and esterified cholesterol by the scavenger receptor pathway $(16,25)$. HDL and apo A-I were able to promote efflux of $\left[{ }^{3} \mathrm{H}\right]$ cholesterol into the medium and decrease the amount of cholesterol available for esterification by ACAT (Fig. 2, $A$ and $B$ ). Peptides $37 \mathrm{pA}$ and $37 \mathrm{aA}$ were also effective in promoting $\left[{ }^{3} \mathrm{H}\right]$ cholesterol efflux and decreasing $\left[{ }^{14} \mathrm{C}\right]$ oleate

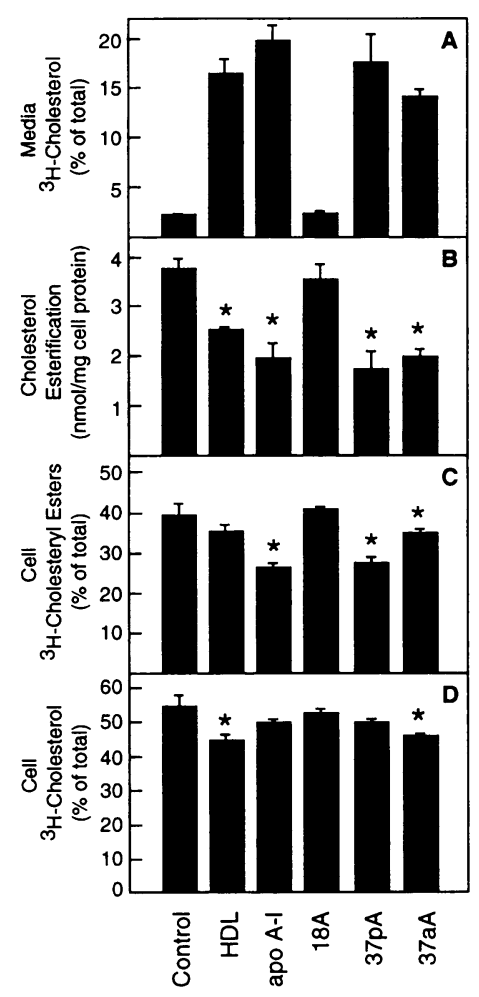

Figure 2. Effect of synthetic amphipathic peptides on cholesterol efflux from mouse peritoneal macrophages. 5-d-old macrophage cultures were incubated for $24 \mathrm{~h}$ with serum-free DME containing $0.5 \mathrm{mg} / \mathrm{ml} \mathrm{BSA}$ and $50 \mu \mathrm{g} / \mathrm{ml}$ acetylatedLDL, which had been labeled with $\left[{ }^{3} \mathrm{H}\right]$ cholesteryl linoleate. Cells were washed and incubated with medium for $18 \mathrm{~h}$ to allow equilibration of cholesterol pools. Cells were incubated with medium containing $0.5 \mathrm{mg} /$ ml BSA alone (control) or with the following additions: $0.36 \mu \mathrm{M}$ HDL, $0.36 \mu \mathrm{M}$ apo A-I, $9.0 \mu \mathrm{M} 18 \mathrm{~A}, 4.5 \mu \mathrm{M}$ $37 \mathrm{pA}$, and $4.5 \mu \mathrm{M} 37 \mathrm{aA}$ After $6 \mathrm{~h}$, the efflux medium was removed and cells were pulse-labeled with ${ }^{14} \mathrm{C}$-oleate to determine cholesterol esterification by ACAT. Media and cell lipids were extracted and subjected to thin-layer

chromatography to determine medium $(A)$ and cellular $(D)\left[{ }^{3} \mathrm{H}\right]-$ cholesterol, cellular $\left[{ }^{3} \mathrm{H}\right]$ cholesteryl esters $(B)$, and ${ }^{14} \mathrm{C}$-oleate incorporated into cellular cholesteryl esters $(C)$. Results are the mean \pm SD of three dishes. Total $\left[{ }^{3} \mathrm{H}\right]$ cholesterol radioactivity was $5,770 \pm 157 \mathrm{cpm} /$ dish for all dishes. Values marked with an asterisk are significantly different from controls by Student's $t$ test; $P<0.005$ in $(B), P$ $<0.05$ in $(C)$ and $(D)$. In $(A)$, all values except those for 18A are significantly different from controls $(P<0.0005)$. 


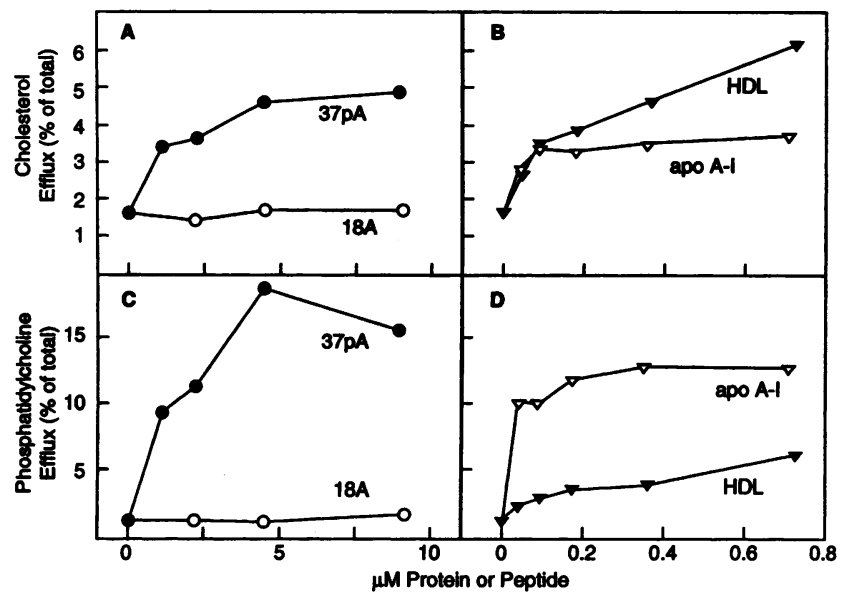

Figure 3. Comparison of the effects of HDL, apo A-I, and synthetic peptides on cholesterol and phosphatidylcholine efflux from cholesterolloaded fibroblasts. Cholesterol-loaded fibroblasts were incubated for 18 $\mathrm{h}$ with serum-free medium containing $1 \mathrm{mg} / \mathrm{ml} \mathrm{BSA}, 0.1 \mu \mathrm{Ci} / \mathrm{ml}\left[{ }^{14} \mathrm{C}\right]-$ cholesterol, and $\left.1.0 \mu \mathrm{Ci} / \mathrm{ml} \mathrm{[}{ }^{3} \mathrm{H}\right]$ choline chloride (to label cellular phosphatidylcholine). Labeled cells were then incubated with the indicated concentrations of HDL or peptides for $6 \mathrm{~h}$. Cell and medium lipids were extracted and separated by thin-layer chromatography to quantitate $\left[{ }^{14} \mathrm{C}\right]$ cholesterol $(A$ and $B)$ and $\left[{ }^{3} \mathrm{H}\right]$ phosphatidylcholine $(C$ and $D)$ (as described in Methods). Efflux was calculated as the percent of total (cell and medium) label appearing in the medium. For $\left[{ }^{3} \mathrm{H}\right]-$

phosphatidylcholine and $\left[{ }^{14} \mathrm{C}\right]$ cholesterol, total counts were $4,049 \pm 121$ and $13,337 \pm 368 \mathrm{cpm} /$ dish, respectively ( \pm SEM). Results are the mean of duplicate dishes. The coefficient of variation was $10.0 \%$ and $9.6 \%$ for phospholipid and cholesterol efflux assays, respectively.

incorporation into cholesterol esters. Peptide 18A was again without effect. The appearance of $\left[{ }^{3} \mathrm{H}\right]$ cholesterol in the medium could be accounted for by decreases in both cell free and esterified cholesterol (Fig. 2, $C$ and $D$ ). apo A-I, 37pA, and 37aA caused a significant decrease in esterified cholesterol content. HDL was less effective at cholesteryl ester clearance, and efflux was due mostly to a loss of free cholesterol. It is noteworthy that the decrease in cell $\left[{ }^{3} \mathrm{H}\right]$ cholesteryl esters by the active peptides and HDL strongly correlated $(r=0.794)$ with the decrease in ACAT-mediated cholesterol esterification. These data demonstrate that apo A-I, 37pA, and 37aA have similar abilities to promote clearance of excess cholesterol from macrophages.

Peptides $18 \mathrm{~A}$ and $37 \mathrm{pA}$ were compared to HDL and apo A-I for their ability to promote cholesterol and phospholipid efflux from cholesterol-loaded fibroblasts (Fig. 3). Dose response curves showed that HDL, apo A-I, and 37pA promoted efflux of both radiolabeled cholesterol and phosphatidylcholine. At saturating concentrations, all three acceptors were able to promote cholesterol efflux to nearly the same extent. In contrast, HDL was much less effective at removing cellular phosphatidylcholine compared to the lipid-free peptides, presumably because its apolipoproteins were already associated with phospholipids. Peptide 18A did not promote efflux of either phosphatidylcholine or cholesterol at the concentrations tested.

Results shown in Fig. 3 suggest that removal of cholesterol from cells by apo A-I or 37pA may be secondary to formation of phospholipid-rich particles that act as cholesterol acceptors. To further test for this possibility, we compared the ability of $37 \mathrm{pA}$ to stimulate cellular cholesterol and phospholipid efflux in the presence or absence of an extracellular source of phospholipid. Addition of phosphatidylcholine vesicles alone to the medium promoted efflux of $\left[{ }^{3} \mathrm{H}\right]$ cholesterol from the plasma membranes of fibroblasts $(0 \mu \mathrm{M} 37 \mathrm{pA}$, Fig. $4 A)$. In contrast, the vesicles had no measurable effect on efflux of $\left[{ }^{3} \mathrm{H}\right]$ phosphatidylcholine during the incubations (Fig. $4 \mathrm{~B}$ ) nor on cholesterol esterification by ACAT (Fig. $4 C$ ) following the 6$h$ incubations. In the presence of phosphatidylcholine vesicles, $37 \mathrm{pA}$ had no additional ability to stimulate $\left[{ }^{3} \mathrm{H}\right]$ cholesterol efflux (compared to vesicles alone) at concentrations up to 2 $\mu \mathrm{M}$. This peptide, however, was still capable of stimulating cellular $\left[{ }^{3} \mathrm{H}\right]$ phosphatidylcholine efflux and inhibiting cholesterol esterification when vesicles were included in the medium, although the half-maximal concentration was increased by twoto threefold. This concentration shift may have been caused by the interaction of $37 \mathrm{pA}$ with phospholipid vesicles. These results support the concept that efflux of plasma membrane cholesterol depends largely on the presence of extracellular phospholipid particles, whereas both efflux of plasma membrane phospholipids and removal of ACAT-accessible cholesterol occur by a separate mechanism, possibly involving the direct interaction of amphipathic helices with cell-surface binding sites. The different mechanisms for removal of $\left[{ }^{3} \mathrm{H}\right]$ cholesterol and ACAT-accessible cholesterol suggest that these sterols reside in different cellular pools.

We have previously demonstrated that binding of HDL to putative cell-surface receptors is required to promote removal of excess cholesterol from the ACAT substrate pools, and that intact apolipoproteins are required for binding (5). To test the possibility that apo A-I and the synthetic peptides are operating by the same mechanism, we compared the ability of different peptides to interact with high-affinity HDL binding sites on the surface of cholesterol-loaded fibroblasts. For these studies, we

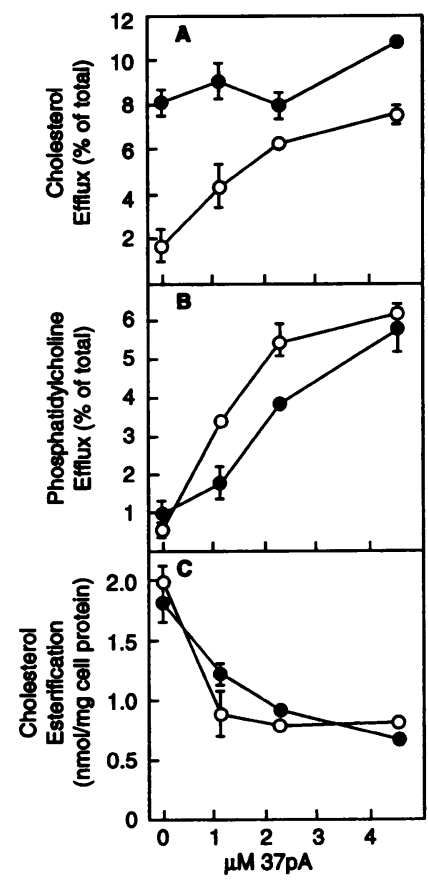

Figure 4. Effect of $37 \mathrm{pA}$ on cholesterol efflux $(A)$, phosphatidylcholine efflux $(B)$, and cholesterol esterification $(C)$ in the presence of phospholipid vesicles. Parallel cultures of cholesterol-loaded human skin fibroblasts were labeled with either $0.2 \mu \mathrm{Ci} / \mathrm{ml}\left[{ }^{3} \mathrm{H}\right]$ cholesterol or $1.0 \mu \mathrm{Ci} / \mathrm{ml}\left[{ }^{3} \mathrm{H}\right]$ choline chloride for $18 \mathrm{~h}$ as described in Methods. The cells were then incubated for $6 \mathrm{~h}$ at $37^{\circ} \mathrm{C}$ with the indicated concentrations of $37 \mathrm{pA}$ in the presence (closed symbols) or absence (open symbols) of $100 \mu \mathrm{g} / \mathrm{ml}$ of phosphatidylcholine vesicles added to the medium immediately prior to the incubations. After incubation, one set of dishes was pulsed with ${ }^{14} \mathrm{C}$-oleate to measure cholesterol esterification as described for Fig. 1. Efflux me$\mathrm{dia}$ and cell layers were analyzed for cholesterol, cholesteryl ester, and phosphatidylcholine radioactivity. For $\left[{ }^{3} \mathrm{H}\right]$ phosphatidylcholine and $\left[{ }^{3} \mathrm{H}\right]$ cholesterol, total counts were $13,848 \pm 1,469$ and $14,114 \pm 135 \mathrm{cpm} /$ dish, respectively $( \pm$ SEM). 


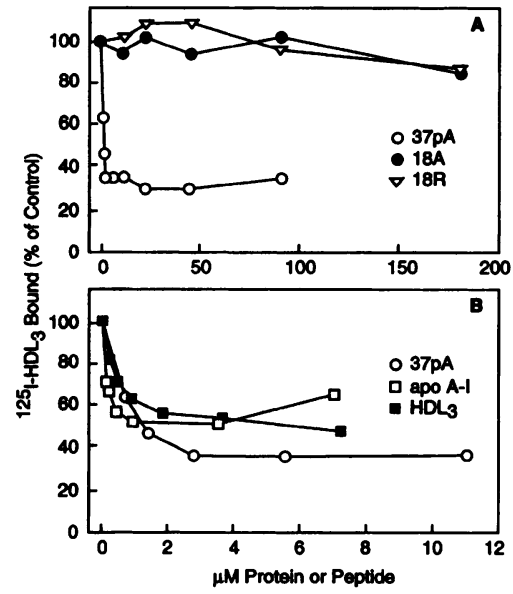

beled HDL was added to each dish, and inc $1 \mathrm{~h}$ on ice. Cells were then washed five times with PBS/BSA and twice with PBS and dissolved in $0.1 \mathrm{M} \mathrm{NaOH}$, and aliquots were taken for ${ }^{125} \mathrm{I}$ and protein determinations. Results are means of duplicate dishes (3.8\% coefficient of variation) representing at least three separate experiments. In the absence of competitors, cells bound $33 \pm 3 \mathrm{ng}{ }^{125}$ I-labeled HDL/mg cell protein $(n=6)$.

used a sequential competitive binding protocol to assay for the ability of different peptides to block high-affinity HDL binding. Cells were first exposed at $0^{\circ} \mathrm{C}$ to increasing concentrations of unlabeled competitor and, after removal of unbound competitor, were then incubated at $0^{\circ} \mathrm{C}$ with ${ }^{125} \mathrm{I}-\mathrm{HDL}$ at a concentration near its high-affinity $K_{\mathrm{d}}$. Because high-affinity HDL binding is essentially irreversible at $0^{\circ} \mathrm{C}(26,27)$, molecules that bind to these sites with similar kinetics as HDL should remain bound during the second $0^{\circ} \mathrm{C}$ incubation and block high-affinity binding of ${ }^{125}$ I-HDL. It was necessary to use a sequential competition assay rather than a more conventional simultaneous incubation to minimize the interaction of peptides and ${ }^{125} \mathrm{I}-\mathrm{HDL}$ in solution, which may produce artifacts due to the displacement of ${ }^{125} \mathrm{I}$ apolipoproteins from HDL particles $(10,23)$. A similar sequential competition assay has been used previously to identify receptor ligands in plasma that interact with other plasma components (22).

Results using the sequential competitive binding assay showed that neither $18 \mathrm{~A}$ nor $18 \mathrm{R}$ could prevent the subsequent binding of ${ }^{125} \mathrm{I}-\mathrm{HDL}$ (Fig. $5 \mathrm{~A}$ ). In contrast, apo A-I and 37pA effectively blocked sites recognized by ${ }^{125} \mathrm{I}$-HDL (Fig. 5, $A$ and $B$ ). These sites were also blocked by $37 \mathrm{aA}$ (data not shown). The concentrations for half-maximal inhibition of ${ }^{125} \mathrm{I}-\mathrm{HDL}$ binding by $\mathrm{HDL}$, apo A-I, and $37 \mathrm{pA}$ were $3 \times 10^{-8} \mathrm{M}, 1$ $\times 10^{-8} \mathrm{M}$, and $5 \times 10^{-8} \mathrm{M}$, respectively. These results indicate that high-affinity HDL binding sites on cholesterol-loaded fibroblasts also interact with apo A-I, 37pA, and 37aA, but not with $18 \mathrm{~A}$ and $18 \mathrm{R}$.

We also examined direct binding of iodinated $37 \mathrm{pA}$ and 18A to cholesterol-loaded fibroblasts (Fig. 6). Both peptides bound extensively to cells, but with different saturation kinetics. Over a concentration range of 0.01 to $2.0 \mu \mathrm{M}, 18 \mathrm{~A}$ binding was nearly linear. At higher concentrations (not shown), some saturability was evident, but these high-capacity binding sites had a relatively low-affinity (apparent $K_{\mathrm{d}}$ of $10^{-5} \mathrm{M}$ ). In contrast, computer analysis of ${ }^{125} \mathrm{I}-37 \mathrm{pA}$ binding indicated that the concentration curve best fit a single saturable binding compo- nent with a $K_{\mathrm{d}}$ of $\sim 2 \times 10^{-7} \mathrm{M}$, plus a linear (nonspecific) component. Thus, 37pA appears to interact with saturable cellsurface binding sites that have a much higher affinity than those for $18 \mathrm{~A}$.

We characterized the specificity of the $37 \mathrm{pA}$ binding sites by competitive binding studies. To assess competition by HDL, we used the sequential competitive binding assay to avoid potential interactions between iodinated $37 \mathrm{pA}$ and lipoprotein particles. At a concentration of iodinated $37 \mathrm{pA}$ near its $K_{\mathrm{d}}$ for highaffinity binding $\left(10^{-7} \mathrm{M}\right)$, pretreatment of cholesterol-loaded fibroblasts with unlabeled $37 \mathrm{pA}$ and $37 \mathrm{aA}$ blocked $40 \%$ of the iodinated 37pA binding in a concentration-dependent and saturable manner (Fig. 7). Pretreatment with 18A had no effect on $37 \mathrm{pA}$ binding, even at concentrations of $18 \mathrm{~A}$ that exhibited twofold greater total cellular binding than $37 \mathrm{pA}$ (Fig. 6). In contrast, pretreatment of cells with apo A-I or HDL blocked approximately $20 \%$ of the $37 \mathrm{pA}$ binding sites (half that blocked by $37 \mathrm{pA}$ ). These results suggest that $37 \mathrm{pA}$ is interacting with multiple high-affinity binding sites on cholesterol-loaded fibroblasts, none of which interact with $18 \mathrm{~A}$ with the same kinetic properties. A subset of these sites, however, appears to bind both HDL and apo A-I, consistent with results showing that $37 \mathrm{pA}$ interacts with the high-affinity HDL binding sites.

\section{Discussion}

Results presented in this report demonstrate that the synthetic peptides $37 \mathrm{pA}$ and $37 \mathrm{aA}$, composed of two 18-mer class $\mathrm{A}$ amphipathic helical repeats (6-11), promoted cholesterol efflux and inhibited cellular cholesterol esterification in both fibroblasts and macrophages. These effects were similar to those mediated by lipid-free apo A-I and HDL, except that HDL had a greater capacity to promote efflux of plasma membrane cholesterol, probably due to exchange of cholesterol between

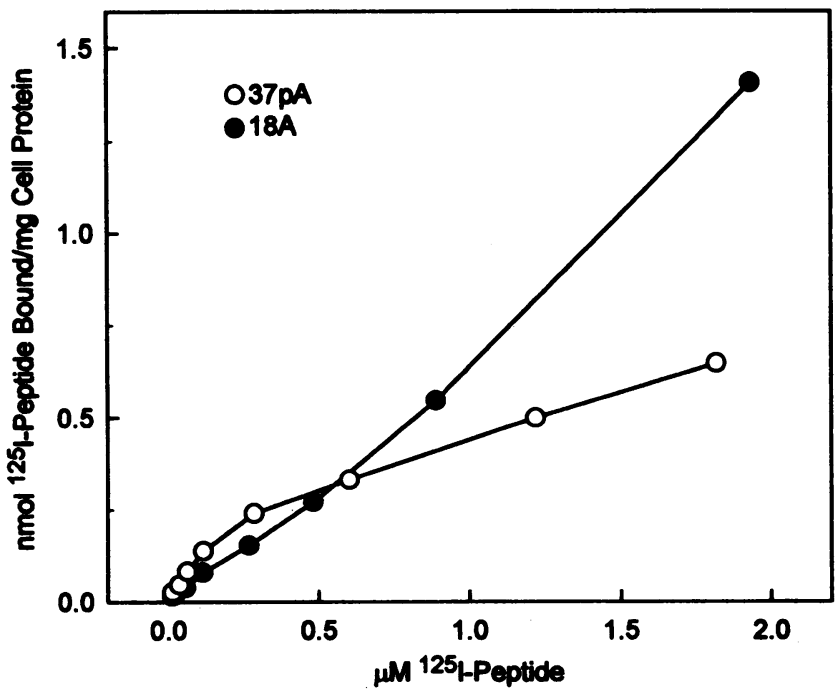

Figure 6. Cell-surface binding of iodinated $18 \mathrm{~A}$ and $37 \mathrm{pA}$ to cholesterolloaded fibroblasts. Cholesterol-loaded human skin fibroblasts were incubated with increasing concentration of iodinated peptide for $3 \mathrm{~h}$ at $4^{\circ} \mathrm{C}$ Then, cells were washed, and radioactivity was determined as described in Fig. 5. The specific activities of ${ }^{125}$ I-labeled $18 \mathrm{~A}$ and ${ }^{125} \mathrm{I}$-labeled $37 \mathrm{pA}$ were 810 and $2,100 \mathrm{cpm} / \mathrm{pmol}$, respectively. Each value represents the mean of duplicate dishes ( $5.5 \%$ coefficient of variation). 


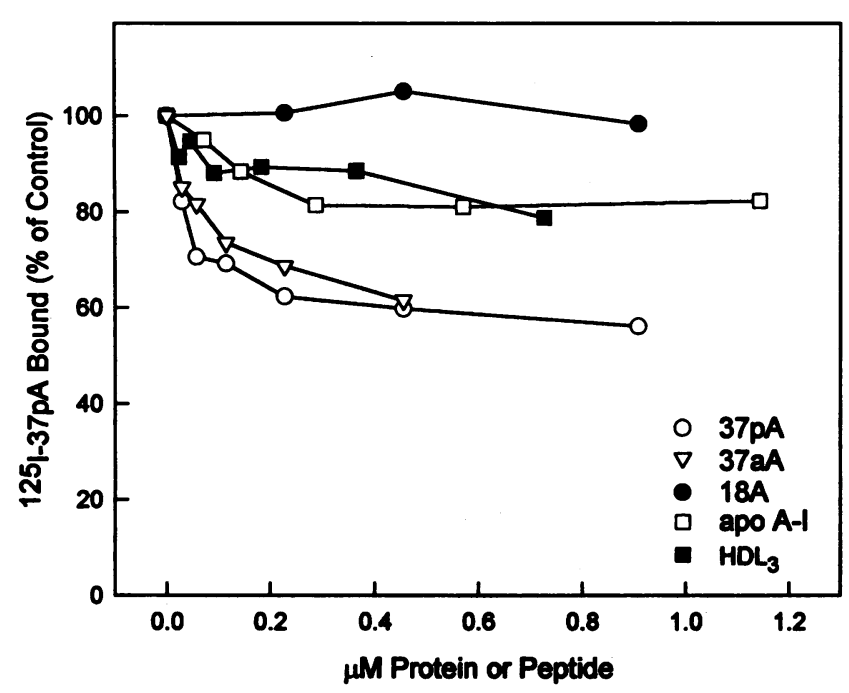

Figure 7. Interaction of HDL, apo A-I, and synthetic peptides with cell surface 37pA binding sites. Cholesterol-loaded fibroblasts were chilled on ice and incubated with ice-cold serum-free medium containing 1 $\mathrm{mg} / \mathrm{ml} \mathrm{BSA}$ and the indicated concentrations of $37 \mathrm{pA}, 37 \mathrm{aA}, 18 \mathrm{~A}$, apo A-I, or HDL. After $3 \mathrm{~h}$, dishes were rinsed three times with PBS/BSA, $1 \mathrm{ml}$ of serum-free medium containing $0.5 \mu \mathrm{g} / \mathrm{ml}(0.11 \mu \mathrm{M}){ }^{125} \mathrm{I}$-labeled $37 \mathrm{pA}$ was added to each dish, and incubations were continued for $1 \mathrm{~h}$ on ice. Cells were treated and radioactivity determined as described in Fig. 5. Total cell binding of ${ }^{125}$ I-labeled $37 \mathrm{pA}$ ( specific activity of 2,100 $\mathrm{cpm} / \mathrm{pmol}$ ) in the absence of competitor was $64 \mathrm{pmol} / \mathrm{mg}$ cell protein. Each value represents the mean of duplicate dishes (3.5\% coefficient of variation).

the lipoprotein particle and cells. Additionally, 37pA and 37aA could promote efflux of cellular $\left[{ }^{3} \mathrm{H}\right]$ phosphatidylcholine, similar to the effects of apo A-I, while HDL had a limited capacity for phospholipid efflux. In contrast to the peptide dimers, peptides containing only a single 18-mer amphipathic helix (18A and Ac-18A-NH $\mathrm{NH}_{2}$ had little or no ability to stimulate cholesterol and phospholipid efflux and to deplete cells of substrate for cholesterol esterification by ACAT. Thus, although these monomers have been shown to interact with lipids and have biological activity (8-15), they were almost completely inactive in mimicking apo A-I or HDL in stimulating lipid transport from cells.

Exposure of fibroblasts to apo A-I or $37 \mathrm{pA}$ increased efflux from the plasma membrane of both cholesterol and phosphatidylcholine in parallel to depletion of ACAT-accessible cholesterol, implying that these three lipid transport processes are mediated by the same cellular interactions. Several other lines of evidence, however, suggest that these processes are occurring by independent mechanisms. First, removal of cholesterol from either the plasma membrane or ACAT substrate pools does not require simultaneous release of plasma membrane phospholipids, as evidenced by results showing that HDL stimulated efflux of both sources of cholesterol to the same extent as $37 \mathrm{pA}$ and apo A-I but had markedly less ability to promote efflux of cellular phospholipids. Second, efflux of radiolabeled cholesterol from the plasma membrane can be dissociated from both phospholipid efflux and depletion of ACAT-accessible cholesterol. For example, addition of phospholipid vesicles to the medium increased cholesterol efflux from the plasma membrane severalfold within $6 \mathrm{~h}$, but there was no significant effect on phosphatidylcholine efflux or depletion of ACAT-accessible cholesterol. Conversely, addition of $37 \mathrm{pA}$ to medium containing phospholipid vesicles increased cellular phosphatidylcholine efflux severalfold and depleted over half of the ACAT-accessible cholesterol when there was no further increase in cholesterol efflux from the plasma membrane.

One explanation for these findings is that, of these three lipid transport processes, only phospholipid efflux and depletion of ACAT-accessible cholesterol involve interactions of amphipathic helices with cell-surface binding sites. Promotion of cholesterol efflux from the plasma membrane may be a secondary response to formation of membrane-derived phospholipid complexes generated by reversible cell-surface binding of peptides or lipid-free apolipoproteins. These newly formed particles may act as sterol acceptors and enhance passive diffusion of cholesterol from the cell surface $(1,2)$. This two-step lipid transport has been postulated for promotion of cholesterol efflux from cells by various lipid-free apolipoproteins $(25,28-31)$. It is likely, however, that removal of plasma membrane phospholipid is significant only for those apolipoproteins that are lipid-deficient. In contrast, the interaction of apolipoproteins with cells depletes ACAT-accessible cholesterol even when the apolipoproteins are associated with HDL phospholipid. This process may be initiated by the release of intracellular signals which activate a cholesterol excretory pathway $(3,4)$.

Competitive binding studies showed that apo A-I, 37pA, and $37 \mathrm{aA}$ blocked the interaction of HDL with its high-affinity binding sites on cholesterol-loaded fibroblasts, while 18A had no effect on HDL binding. These results strongly suggest that the interaction of HDL with its cell-surface binding site is mediated by two or more tandem repeats of class A amphipathic helices within HDL apolipoproteins. Thus, peptides containing two of these amphipathic helices can mimic apo A-I in both stimulating lipid transport from cells and in binding to highaffinity HDL binding sites. The higher efficacy of the dimeric peptides compared to the monomers cannot be explained by an extension of the polar and nonpolar faces along the helical axis, for linkage of the two 18-mer helices by a single amino acid causes a $35^{\circ}$ rotation of these faces. Moreover, linkage by proiine compared to alanine causes a "kink" between the axes, yet $37 \mathrm{pA}$ and $37 \mathrm{aA}$ were equally active. It is most likely that cooperativity between two or more amphipathic helices is required for optimum binding to high-affinity sites on the cell surface, as has been described previously for the interaction of HDL apolipoproteins with cells $(28,32)$. This property may confer specificity for lipid-poor subclasses of HDL particles which have more helices exposed for cellular interactions ( 7 , 33, 34).

Studies with iodinated peptides revealed that both $18 \mathrm{~A}$ and $37 \mathrm{pA}$ bind extensively to the surface of cholesterol-loaded fibroblasts, but only $37 \mathrm{pA}$ binds to saturable, high-affinity sites. High-affinity binding of $37 \mathrm{pA}$ was not blocked by $18 \mathrm{~A}$ and was only partially blocked by HDL and apo A-I, suggesting that none of these $37 \mathrm{pA}$ binding sites interacts with $18 \mathrm{~A}$ and only a subset interacts with HDL apolipoproteins. Therefore, although both apo A-I and 37pA are recognized by HDL binding sites, $37 \mathrm{pA}$ appears to have unique properties that promote its binding to additional cell-surface sites that do not bind 18A, apo A-I, or HDL.

Previous studies showed that modifying HDL so as to decrease its interaction with cellular high-affinity binding sites also reduces its ability to remove excess cellular cholesterol $(4,5,35-37)$, suggesting that these two processes are closely 
coupled. The findings that both high-affinity binding to cells and removal of cellular cholesterol require two or more tandem amphipathic helices further support this concept. The current study, however, does not provide direct evidence that HDL, apo A-I, and dimeric peptides are removing cellular lipids through their interactions with a common binding site. The interactions of amphipathic helices with the plasma membrane are complex and appear to involve multiple binding sites, and the relative contribution of each of these sites to lipid transport processes is unknown. In addition, comparisons of saturation curves revealed that the apparent half-maximal concentrations for inhibition of HDL binding were approximately fivefold lower than those for removing cholesterol. However, this may reflect some of the special conditions of these assays, particularly the different temperatures used $\left(37^{\circ} \mathrm{C}\right.$ vs. $\left.0^{\circ} \mathrm{C}\right)$. The kinetics of highaffinity HDL binding is highly temperature sensitive, in that the dissociation rate is much faster at $37^{\circ} \mathrm{C}$ than at $0^{\circ} \mathrm{C}(26,27)$. Moreover, the active conformation of lipid-free amphipathic peptides in solution may vary with temperature. Despite these differences between assays, the relative efficacy of the peptides was similar for each process. The half-maximal molar concentrations for stimulation of cholesterol efflux and inhibition of HDL binding were approximately fivefold higher for 37pA than for apo A-I. This may be related to the fact that apo A-I has a molecular mass six times that of $37 \mathrm{pA}$ and contains four times the number of amphipathic helices. These and other peptide analogues will be useful tools for testing the hypothesis that HDL apolipoproteins stimulate clearance of cellular cholesterol through the cooperative interaction of their amphipathic helices with cell-surface binding sites or receptors.

Numerous population studies have shown an inverse correlation between plasma HDL levels and risk for coronary heart disease, suggesting that HDL protects against atherosclerosis. This may be related to the ability of HDL apolipoproteins to stimulate clearance of cholesterol from peripheral cells, particularly those of the artery wall. The finding that synthetic peptides with structural features of HDL apolipoproteins can mimic the biological activity of HDL raises the possibility that specific agonists could be developed for the cellular cholesterol excretory pathway. These agonists may have therapeutic benefits for the prevention of coronary heart disease.

\section{Acknowledgments}

We would like to acknowledge Rosario Bowen for technical support, and Julie Kirk and Pat Burns for assistance in preparation of the manuscript. This study was supported by National Institutes of Health grants HL-31194, HL-18645, and HL-34343.

\section{References}

1. Phillips, M. C., W. J. Johnson, and G. H. Rothblat. 1987. Mechanisms and consequences of cellular cholesterol exchange and transfer. Biochim. Biophys. Acta. 906:223-276.

2. Johnson, W. J., F. H. Mahlberg, G. H. Rothblat, and M. C. Phillips. 1991. Cholesterol transport between cells and high-density lipoproteins. Biochim. Biophys. Acta. 1085:273-298.

3. Theret, N., C. Delbart, G. Aguie, J. D. Fruchart, G. Vassaux, and G Ailhaud. 1990. Cholesterol efflux from adipose cells is coupled to diacylglycerol production and protein kinase $\mathrm{C}$ activation. Biochem. Biophys. Res. Commun. 173:1361-1368.

4. Mendez, A. J., J. F. Oram, and E. L. Bierman. 1991. Protein kinase C as a mediator of high density lipoprotein receptor-dependent efflux of intracellular cholesterol. J. Biol. Chem. 266:10104-10111.
5. Oram, J. F., A. J. Mendez, J. P. Slotte, and T. F. Johnson. 1991. High density lipoprotein apolipoproteins mediate removal of sterol from intracellular pools but not from plasma membranes of cholesterol-loaded fibroblasts. Arterioscler. Thromb. 11:403-414.

6. Segrest, J. P., H. DeLoof, J. G. Dohlman, C. G. Brouillette, and G. M Anantharamaiah. 1990. Amphipathic helix motifs: classes and properties. Proteins. 8:103-117.

7. Segrest, J. P., M. K. Jones, H. DeLoof, C. G. Brouillette, Y. V. Venkatachalapathi, and G. M. Anantharamaiah. 1992. The amphipathic helix in the exchangeable apolipoproteins: a review of secondary structure and function. J. Lipid Res. 33:141-166.

8. Kanellis, P., A. Y. Romans, B. J. Johnson, H. Kercret, R. Chiovetti, Jr., T. M. Allen, and J. P. Segrest. 1980. Studies of synthetic peptide analogs of the amphipathic helix. Effect of charged amino acid topography on lipid affinity. $J$. Biol. Chem. 255:11464-11472.

9. Anantharamaiah, G. M., J. L. Jones, C. G. Brouillette, C. F. Schmidt, B. H. Chung, T. A. Hughes, A. S. Bhown, and J. P. Segrest. 1985. Studies of synthetic peptide analogs of the amphipathic helix. J. Biol. Chem. 260:1024810255.

10. Chung, B. H., G. M. Anantharamaiah, C. G. Brouillette, T. Nishida, and J. P. Segrest. 1985. Studies of synthetic peptide analogs of the amphipathic helix: correlation of structure with function. J. Biol. Chem. 260:10256-10262.

11. Epand, R. M., A. Gawish, M. Iqbal, K. B. Gupta, C.-H. Chen, J. P. Segrest, and G. M. Anantharamaiah. 1987. Studies of synthetic peptide analogs of the amphipathic helix. J. Biol. Chem. 262:9389-9396.

12. Joregenson, E. V., G. M. Anantharamaiah, J. P. Segrest, J. T. Gwynne, and S. Handwerger. 1989. Synthetic amphipathic peptides resembling apolipoproteins stimulate the release of human placenta lactogen. J. Biol. Chem. 264:9215-9219.

13. Blackburn, W. D., J. G. Dohlman, Y. V. Venkatachalapathi, D. J. Pillion, W. J. Koopman, J. P. Segrest, and G. M. Anantharamaiah. 1991. Apolipoprotein A-I decreases neutrophil degranulation and superoxide production. J. Lipid Res. 32:1911-1918.

14. Owens, R. J., G. M. Anantharamaiah, J. B. Kahlon, R. V. Srinivas, R. W. Compans, and J. P. Segrest. 1990. Apolipoprotein A-I and its amphipathic peptide analogues inhibit human immunodeficiency virus-induced synctium formation. $J$. Clin. Invest. 86:1142-1150.

15. Venkatachalapathi, Y. V., M. C. Phillips, R. M. Epand, R. F. Epand, E. M. Tytler, J. P. Segrest, and G. M. Anantharamaiah. 1993. The effect of end group modification on the properties of class A amphipathic peptides. Proteins. 15:349-359.

16. Goldstein, J. L., Y. K. Ho, S. K. Basu, and M. S. Brown. 1979. Binding site on macrophages that mediate uptake and degradation of acetylated low density lipoprotein, producing massive cholesterol deposition. Proc. Natl. Acad. Sci. USA. 76:333-337.

17. Oram, J. F. 1986. Receptor-mediated transport of cholesterol between cultured cells and high density lipoproteins. Methods Enzymol. 129:645-659.

18. Bilheimer, D. W., S. Eisenberg, and R. I. Levy. 1972. The metabolism of very low density lipoprotein proteins. Biochim. Biophys. Acta. 260:212-221.

19. Albers, J. J., C-H. Chen, and A. G. Lacko. 1986. Isolation, characterization, and assay of lecithin-cholesterol acyltransferase. Methods Enzymol. 129:691-704.

20. Edelson, P. J., and Z. A. Cohn. 1976. Purification and cultivation of monocytes and macrophages. In In Vitro Methods in Cell Mediated and Tumor Immunity. B. R. Bloom and J. R. David, editors. Academic Press, New York. $333-340$.

21. Folch, J., M. Lees, and G. H. Sloane-Stanley. 1957. A simple method for the isolation and purification of total lipids from animal tissues. J. Biol. Chem. 226:497-509.

22. Bowen-Pope, D. F., and R. Ross. 1985. Methods for studying the plateletderived growth factor receptor. Methods Enzymol. 109:69-100.

23. Garber, D. W., Y. V. Venkatachalapathi, K. B. Gupta, J. Ibdah, M. C. Phillips, J. B. Hazelrig, J. P. Segrest, and G. M. Anantharamaiah. 1992. Turnover of synthetic class A amphipathic peptide analogues of exchangeable apolipoproteins in rats. Arterioscler. Thromb. 12:886-894.

24. Lowry, O. H., N. J. Rosebrough, A. L. Farr, and R. J. Randall. 1951. Protein measurement with the Folin phenol reagent. J. Biol. Chem. 193:265-275.

25. Hara, H., and S. Yokoyama. 1991. Interaction of free apolipoproteins with macrophages. J. Biol. Chem. 266:3080-3086.

26. Oram, J. F., E. A. Brinton, and E. L. Bierman. 1983. Regulation of high density lipoprotein receptor activity in cultured human skin fibroblasts and human arterial smooth muscle cells. J. Clin. Invest. 72:1611-1621.

27. Oram, J. F., C. J. Johnson, and T. A. Brown. 1987. Interaction of high density lipoprotein with its receptor on cultured fibroblasts in macrophages: evidence for reversible binding at the cell surface without internalization. J. Biol. Chem. 262:2405-2410.

28. Hara, H. H., M. Hiroko, A. Komaba, and S. Yokoyama. 1992. $\alpha$-Helical requirements for free apolipoproteins to generate $\mathrm{HDL}$ and to induce cellular lipid efflux. Lipids. 27:302-304.

29. Hara, H., and S. Yokoyama. 1992. Role of apolipoproteins in cholesterol 
efflux from macrophages to lipid microemulsion: proposal of a putative mode for the pre- $\beta$ high density lipoprotein pathway. Biochemistry. 31:2040-2046.

30. Bielicki, J. K., W. J. Johnson, R. B. Weinberg, J. M. Glick, and G. H. Rothblat. 1992. Efflux of lipid from fibroblasts to apolipoproteins: dependence on elevated levels of cellular unesterified cholesterol. J. Lipid Res. 33:1699-1709.

31. Forte, T. M., R. Goth-Goldstein, R. W. Nordhausen, and M. R. McCall. 1993. Apolipoprotein A-I cell membrane interaction: extracellular assembly of heterogeneous nascent HDL particles. J. Lipid Res. 34:317-324.

32. Leblond, L., and Y. L. Marcel. 1991. The amphipathic alpha-helical repeats of apolipoprotein A-I are responsible for binding of high density lipoproteins to HepG2 cells. J. Biol. Chem. 266:6058-6067.

33. Rothblat, G. H., F. H. Mahlberg, W. J. Johnson, and M. C. Phillips. 1992 Apolipoproteins, membrane cholesterol domains, and the regulation of cholesterol efflux. J. Lipid Res. 33:1091-1098.
34. Jonas, A., A. Steinmetz, and L. Churgay. 1993. The number of amphipathic a-helical segments of apolipoproteins A-I, E, and A-IV determines the size and functional properties of their reconstituted lipoprotein particles. J. Biol. Chem 268:1596-1602.

35. Brinton, E. A., J. F. Oram, C.-H. Chen, J. J. Albers, and E. L. Bierman 1986. Binding of high density lipoprotein to cultured fibroblasts after chemical alteration of apoprotein amino acid residues. J. Biol. Chem. 261:495-503.

36. Duell, P. B., J. F. Oram, and E. L. Bierman. 1990. Nonenzymatic glycosylation of HDL resulting in inhibition of high-affinity binding to cultured human fibroblasts. Diabetes. 39:1257-1263.

37. Duell, P. B., J. F. Oram, and E. L. Bierman. 1991. Nonenzymatic glycosylation of HDL and impaired HDL-receptor-mediated cholesterol efflux. Diabetes. 40:377-384. 